\title{
An insight into the passivation of cupronickel alloys in chloride environment
}

\author{
J MATHIYARASU, N PALANISWAMY and V S MURALIDHARAN* \\ Corrosion Science and Engineering Division, Central Electrochemical \\ Research Institute, Karaikudi 630 006, India \\ e-mail: corr@cscecri.ren.nic.in
}

MS received 19 August 2000; revised 2 December 2000

\begin{abstract}
Cupronickels offer enhanced corrosion protection in marine environments by the formation of passive films on the surface. Cyclic voltammetric studies were carried on cupronickels in chloride solutions at $p \mathrm{H} 6.3$ to understand the role of chloride ions in passive film formation. Increase in nickel content of the alloy and of chloride ions in solution decreases film resistance. Chloride ions take part in reduction of the passive film to copper. A solid-state model for passive film formation involving chloride ions has been attempted.
\end{abstract}

Keywords. Cupronickels; passivation; solid-state model; cyclic voltammetry; marine environment.

\section{Introduction}

Cupronickels are widely used in chloride environments due to their marked corrosion resistance. The corrosion resistance of these alloys is due to passivation, which occurs at a critical electron-to-atom ratio of copper and nickel at which the $d$ shell becomes unfilled $^{1,2}$. The passivation in chloride solutions is due to a protective oxide layer. In synthetic seawater, the layer is found to contain $\mathrm{Cu}_{2} \mathrm{O}, \mathrm{Cu}_{2}(\mathrm{OH})_{3} \mathrm{Cl}$ while in $\mathrm{NaCl}$ solutions the layer dissolves to form soluble $\mathrm{CuCl}_{2}{ }^{-}$complexes ${ }^{3}$. Nickel dissolves to form its corrosion products because of its greater solubility. The dissolution of copper results in the formation of an outer $\mathrm{Cu}_{2}(\mathrm{OH})_{3} \mathrm{Cl}$ layer with an inner $\mathrm{Cu}_{2} \mathrm{O}$ layer ${ }^{4-7}$. In synthetic seawater, the film formed on 90/10 cupronickels contains mainly $\mathrm{Cu}_{2} \mathrm{O}$ with a small amount of $\mathrm{Ni}^{2+}, \mathrm{Ni}^{3+}$ and chloride ions in the inner layer ${ }^{8}$. This $\mathrm{Cu}_{2} \mathrm{O}$ film grows till the potential of the outer film surface reaches that of $\mathrm{Cu}_{2}(\mathrm{OH})_{3} \mathrm{Cl}$. After sometime, the inner layer stops growing and a non-protective porous outer layer of $\mathrm{Cu}_{2}(\mathrm{OH})_{3} \mathrm{Cl}$ is formed ${ }^{9-10}$.

Cupronickel alloys containing up to $40 \mathrm{wt} \%$ nickel are particularly interesting since it has been shown that corrosion rates decrease with increasing nickel content from 10 to $40 \%$ and then remain constant ${ }^{11}$. Films formed on the alloys containing more than 40 $\mathrm{wt} \%$ of copper (if the atomic ratio of $\mathrm{Cu} / \mathrm{Ni}$ exceeds 1.6 ) are less stable ${ }^{12}$. In low chloride solutions, a nickel-rich alloy undergoes pitting while in higher chloride solutions passivation takes place. Interesting behaviour of $\mathrm{Cu}-\mathrm{Ni}$ alloys is observed in the presence of chloride ions, where passive layers formed on these materials suffer localised breakdown. Various authors attempted to understand the effect of chloride ion concentration

*For correspondence 
on the passivation behaviour of cupronickels. A critical chloride concentration, below which the resistance to localised corrosion increases with decreasing nickel content and also above which it increases with nickel content has been reported ${ }^{13}$. The present investigation focuses on the role of chloride ions in the formation of passive films on cupronickels with varying nickel content. A solid-state model has also been attempted.

\section{Experimental details}

Different cupronickel alloys were made from pure metals in inert atmosphere, and then mechanically treated and heat-treated to obtain void-free single-phase materials. Compositions of the alloys used in this study are given in table 1 . The alloys were made into cylindrical rods having area of cross-section $=0.385 \mathrm{~cm}^{2}$. The rods were embedded in teflon gaskets and electrically connected by screw and thread arrangements. The rods were mechanically polished with $1 / 0,2 / 0,3 / 0$ and 4/0 emery papers. Three-electrode cell assemblies were used. Large platinum foils were used as auxiliary electrodes and

Table 1. Compositions (wt $\%$ ) of experimental cupronickel alloys used as working electrodes.

\begin{tabular}{lcc}
\hline Cupronickels & Copper \% & Nickel \% \\
\hline Alloy A & 85 & 15 \\
Alloy B & 73 & 27 \\
Alloy C & 65 & 35 \\
\hline
\end{tabular}

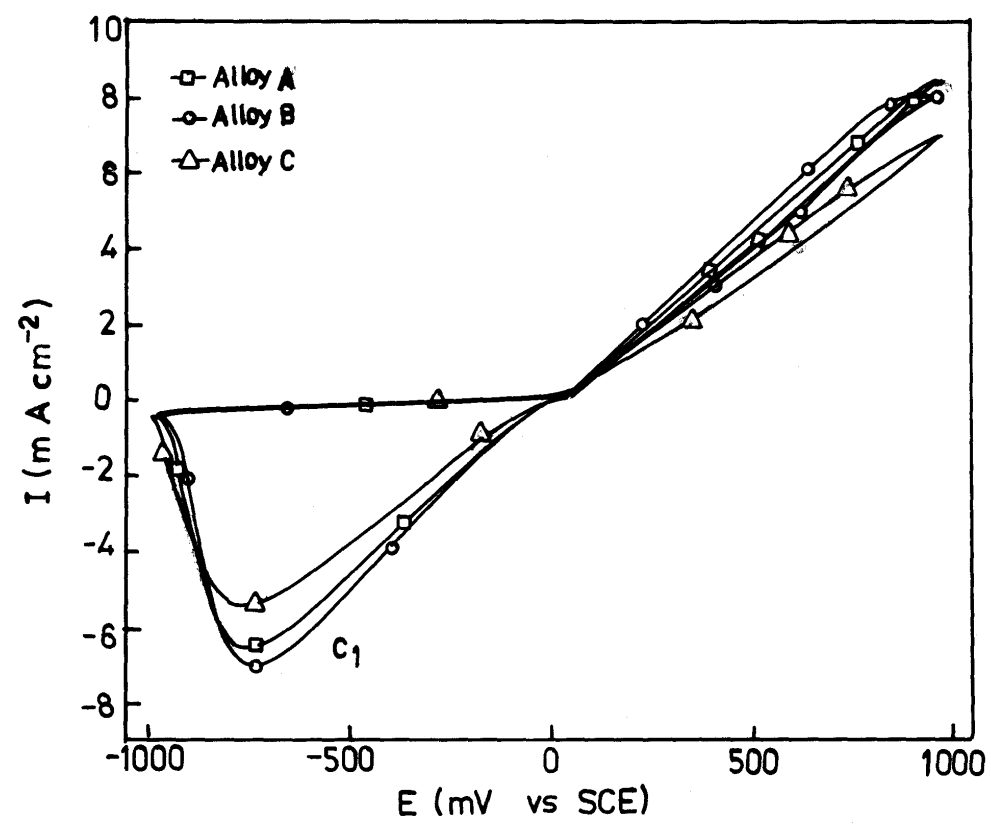

Figure 1. Cyclic voltammograms of cupronickel alloys in $0.02 \mathrm{M}$ chloride solution at $10 \mathrm{mV} / \mathrm{s}$ sweep rate, $\varepsilon_{\lambda, c}=-1.0 \mathrm{~V}, \varepsilon_{\lambda, a}=1.0 \mathrm{~V}$. 
saturated calomel electrodes as reference. Triangular potential sweep experiments were carried out using an electrochemical analyser BAS 100 A. Voltammograms were obtained from $-1000 \mathrm{mV}$ to $1000 \mathrm{mV}$ at various sweep rates $(5-100 \mathrm{mV} / \mathrm{s})$ in $0.02\langle x\rangle$ $0.5 \mathrm{M}$ sodium chloride solutions at $p \mathrm{H} \mathrm{6.3}$. After cycling between 0 to $600 \mathrm{mV}$, the surface of the alloy $\mathrm{C}$ was seen under scanning electron microscope at different magnifications.

X-ray diffraction studies of the film formed on the alloy surface were carried out by using a computer-controlled X-diffractometer (JOEL 8030) with $\mathrm{CuK}_{\propto}$ radiation $(\lambda=1.5418 \AA)$ at a rating of $40 \mathrm{kV}, 20 \mathrm{~mA}$. The scan rate was 0.05 per step and the measuring time was one second per step.

XPS studies were carried out using ESCA-Lab 2000 (VG scientific instruments) and the surface was sputtered as required by argon ion bombardments. A delocalised $\mathrm{Ar}^{+}$ion beam accelerated under $2 \mathrm{keV}$ was used to remove adsorbed contaminants on the surface ( $0.05 \mu / \mathrm{m}^{2}$ current density). The excitation source used was the unmonochromatised Al $\mathrm{K}_{\propto}(h \gamma=1486.6 \mathrm{eV})$. The spectra were recorded at a vacuum better than $7 \cdot 1 \times 10^{-7} \mathrm{~N} / \mathrm{m}^{2}$.

SEM micrographs of electrodes polarized at different anodic potentials were obtained to correlate the electrochemical and surface morphological data. A scanning electron microscope model HITACHI-S $3000 \mathrm{H}$ was used.

\section{Results}

\subsection{Behaviour of cupronickels in different chloride concentrations}

3.1a Electrochemical behaviour in 0.02 M chloride solutions: When polarised from -1000 to $1000 \mathrm{mV}$, the forward scan exhibited no peak in all the cupronickel alloys studied. In the case of alloy $\mathrm{C}$, the reverse scan showed a cathodic peak at $-774 \mathrm{mV}$ which became more negative with sweep rates. When the nickel content was reduced to $20 \%$, the alloy exhibited a cathodic peak at $-658 \mathrm{mV}$; on further decrease of nickel content to $10 \%$, the reverse scan showed cathodic peaks at $-662 \mathrm{mV}$ and $-512 \mathrm{mV}$ which became active with sweep rates (figure 1).

3.1b Electrochemical behaviour in $0.05 \mathrm{M}$ chloride solutions: When polarised from -1000 to $1000 \mathrm{mV}$, the forward scan exhibited an anodic peak at $539 \mathrm{mV}$ followed by oxygen evolution for alloy $\mathrm{C}$. The reverse scan revealed an inverted anodic peak at $458 \mathrm{mV}$ followed by a well-defined cathodic peak at $-555 \mathrm{mV}$. In the case of alloy $\mathrm{B}$, the anodic peak appeared at $469 \mathrm{mV}$, while the cathodic peak was at $-471 \mathrm{mV}$. When the nickel percentage in the alloy was reduced to $10 \%$, the anodic peak was not observed during the forward scan while the reverse scan showed two cathodic peaks at $-662 \mathrm{mV}$ and $-512 \mathrm{mV}$ (figure 2).

3.1c Electrochemical behaviour in 0.1 M chloride solutions: During the forward scan of alloy $\mathrm{C}$, an anodic peak appeared at $372 \mathrm{mV}$ which became nobler with sweep rate; the reverse scan exhibited an inverted anodic peak at $235 \mathrm{mV}$ and a cathodic peak at $-417 \mathrm{mV}$. Alloy B exhibited a shoulder around $609 \mathrm{mV}$ preceded by an anodic peak at $310 \mathrm{mV}$. The reverse scan exhibited a broad cathodic peak at $-373 \mathrm{mV}$ which became active with sweep rate. During the forward scan alloy A exhibited a shoulder at $234 \mathrm{mV}$ followed by oxygen evolution. The reverse scan exhibited a peak at $-383 \mathrm{mV}$ which became active with sweep rate (figure 3 ). 


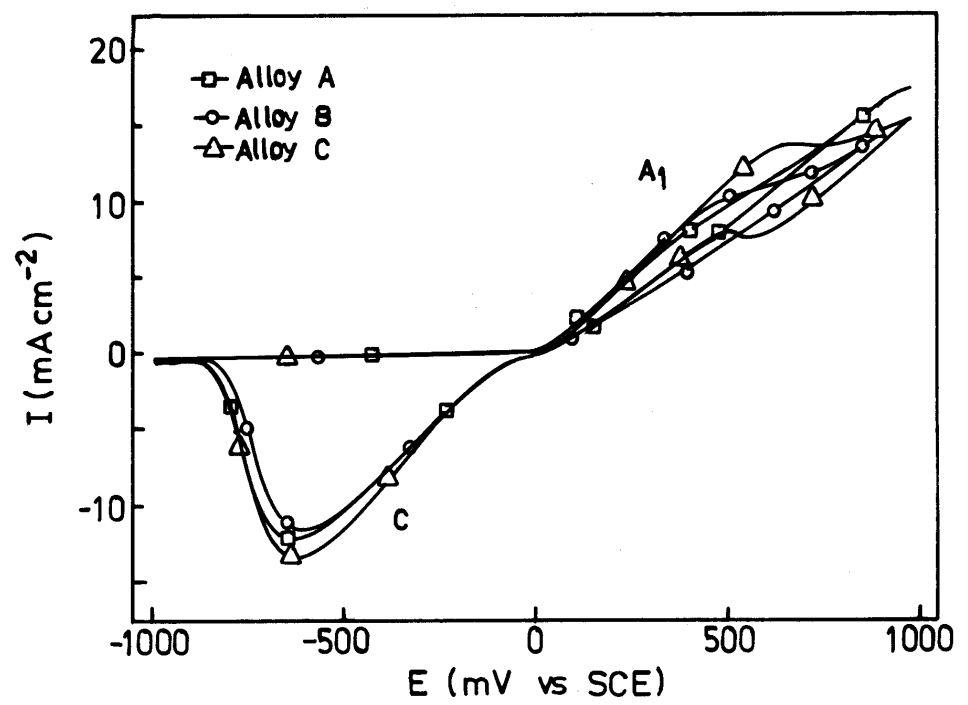

Figure 2. Cyclic voltammograms of cupronickel alloys in $0.05 \mathrm{M}$ chloride solution at $10 \mathrm{mV} / \mathrm{s}$ sweep rate, $\varepsilon_{\lambda, c}=-1.0 \mathrm{~V}, \varepsilon_{\lambda, a}=1.0 \mathrm{~V}$.

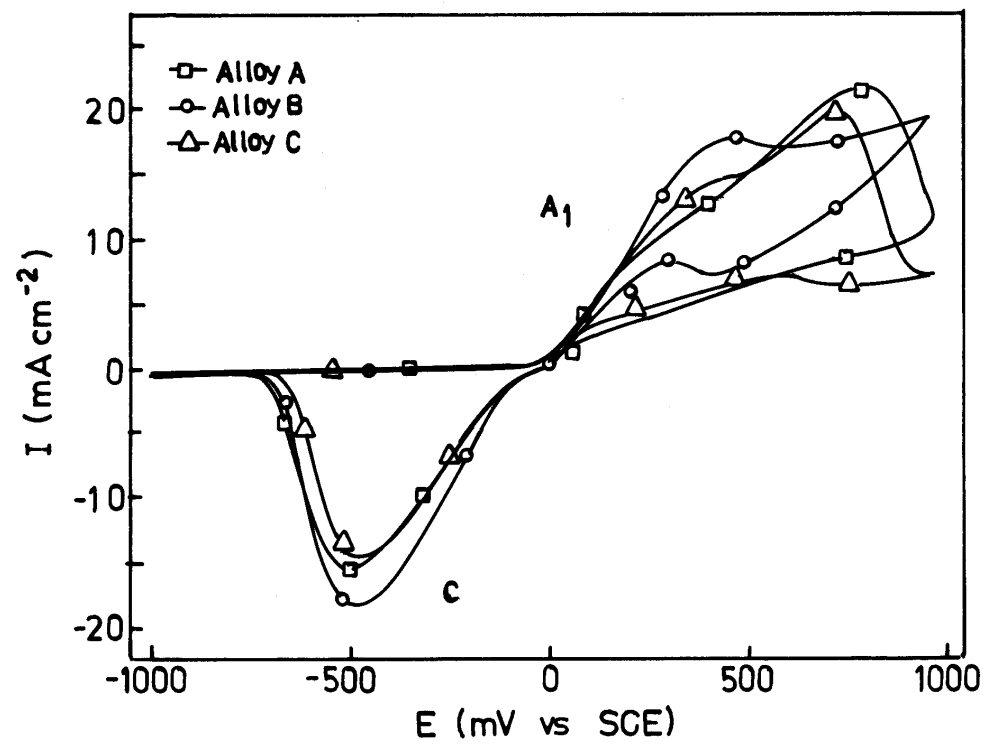

Figure 3. Cyclic voltammograms of cupronickel alloys in $0 \cdot 01 \mathrm{M}$ chloride solution at $10 \mathrm{mV} / \mathrm{s}$ sweep rate, $\varepsilon_{\lambda, c}=-1.0 \mathrm{~V}, \varepsilon_{\lambda, a}=1.0 \mathrm{~V}$.

3.1d Electrochemical behaviour in 0.2 M chloride solutions: When polarised from -1000 to $1000 \mathrm{mV}$, the forward scan exhibited an anodic peak at $298 \mathrm{mV}$ and the cathodic peak at $-354 \mathrm{mV}$ for alloy C. Two anodic peaks were observed at $191 \mathrm{mV}$ and 
$467 \mathrm{mV}$ for alloy B and these potentials became nobler with sweep rate. The reverse scan exhibited an inverted anodic peak at $133 \mathrm{mV}$ followed by a cathodic peak at $294 \mathrm{mV}$. Similar behaviour was observed for alloy A. The forward scan exhibited anodic peaks at $143 \mathrm{mV}$ and $446 \mathrm{mV}$ and an inverted anodic peak at $330 \mathrm{mV}$ followed by a cathodic peak at $-283 \mathrm{mV}$ in the reverse scan (figure 4).

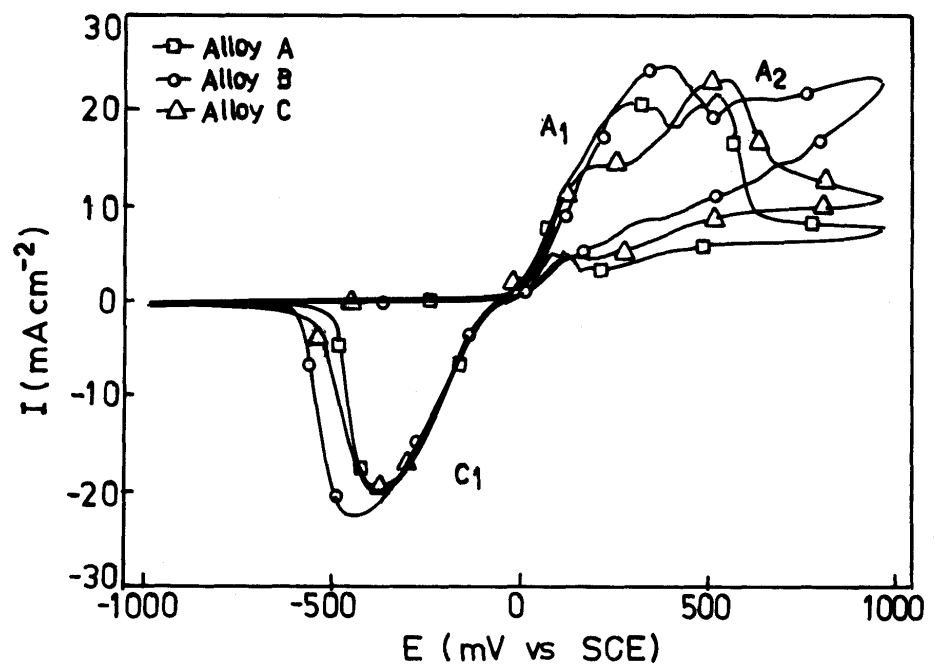

Figure 4. Cyclic voltammograms of cupronickel alloys in $0 \cdot 2 \mathrm{M}$ chloride solution at $10 \mathrm{mV} / \mathrm{s}$ sweep rate, $\varepsilon_{\lambda, c}=-1.0 \mathrm{~V}, \varepsilon_{\lambda, a}=1.0 \mathrm{~V}$.

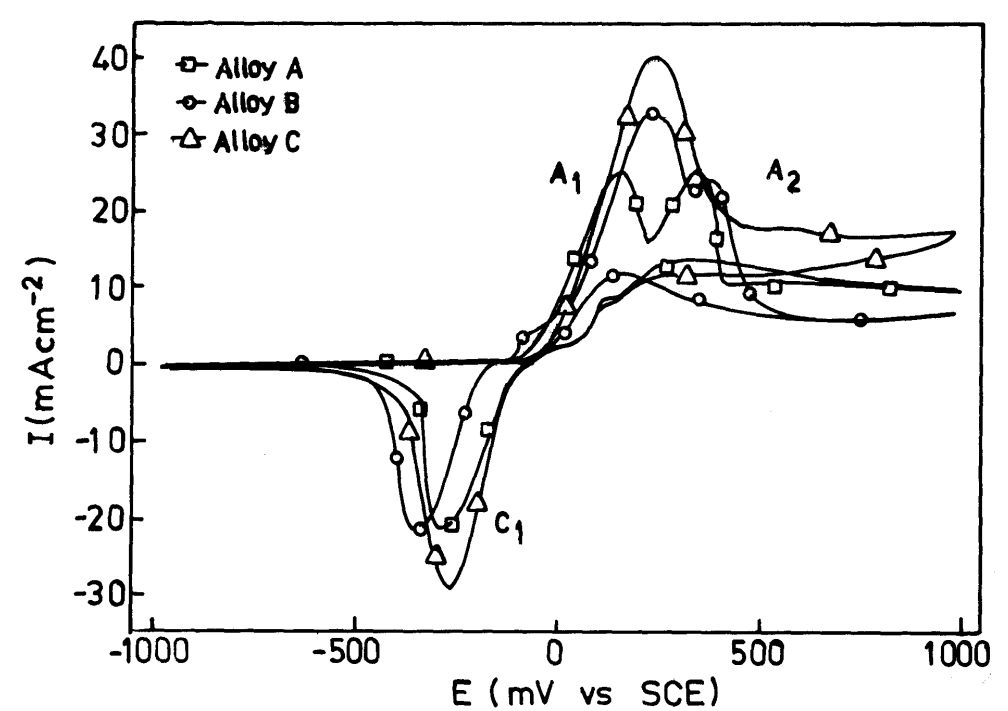

Figure 5. Cyclic voltammograms of cupronickel alloys in $0.5 \mathrm{M}$ chloride solution at $10 \mathrm{mV} / \mathrm{s}$ sweep rate, $\varepsilon_{\lambda, c}=-1.0 \mathrm{~V}, \varepsilon_{\lambda, a}=1.0 \mathrm{~V}$. 
3.1e Electrochemical behaviour in 0.5 M chloride solutions: During the forward scan, alloy $\mathrm{C}$ exhibited a single anodic peak at $150 \mathrm{mV}$, and an inverted shoulder at $10 \mathrm{mV}$ followed by a cathodic peak at $-230 \mathrm{mV}$. Alloy B exhibited a sharp anodic peak at $130 \mathrm{mV}$ followed by another peak at $270 \mathrm{mV}$. The reverse scan revealed a large inverted broad anodic peak at $180 \mathrm{mV}$, while the inverted shoulder became a distinct plateau at $-30 \mathrm{mV}$; the cathodic peak appeared at $-190 \mathrm{mV}$. When the nickel content in the alloy was $10 \%$, an anodic peak was seen at $90 \mathrm{mV}$ followed by a peak at $200 \mathrm{mV}$. In the reverse scan an inverted shoulder appeared at $-60 \mathrm{mV}$; a distinct cathodic peak also appeared at $-200 \mathrm{mV}$ (figure 5).

\section{$3.2 X$-ray diffraction analysis}

Figure 6 presents the XRD patterns obtained for alloy $\mathrm{C}$, at $+200 \mathrm{mV}$ in $0.5 \mathrm{M}$ solutions. The surface is found to have $\mathrm{Cu}_{3} \mathrm{Ni}_{8}$ as suggested by the $d$-spacing values of $2 \cdot 079,1.799$ and 1.267 . Oxidation of copper resulting in $\mathrm{Cu}_{2} \mathrm{O}$ is inferred by the $d$-spacing values of $2 \cdot 469,2 \cdot 137$ and $1 \cdot 511$

\subsection{ESCA analysis}

The alloy $\mathrm{C}$ was maintained at desired potentials to identify the oxidation states of elements present underneath the surface film. The chemical compounds present in the passive film were determined from the detailed examination of oxidation states of elements present.

Figures 7 and 8 show the ESCA survey spectra $(0-1000 \mathrm{eV})$ obtained from the surface exposed at various anodic potentials. The surface contamination was removed by etching the surface with $\mathrm{Ar}^{+}$ions. The survey scans indicated that the main elements in the film were $\mathrm{Cu}, \mathrm{O}, \mathrm{C}$ and traces of chloride and nickel. With increasing potential the signals corresponding to metallic copper and nickel decreased and contributions of signals at higher binding energies grew due to the formation of oxides and hydroxides. The surface kept at $-200 \mathrm{mV}$, revealed the lack of shake-up satellite for both $2 P 3 / 2$ and $2 P 1 / 2$ suggesting the existence of elemental copper to be in the metallic form or in the cuprous form. No appreciable signal from the nickel couple was obtained at $-200 \mathrm{mV}$. At $0 \mathrm{mV}$, the appearance of $\mathrm{Cu} .2 P 3 / 2$ peak with satellites suggested that the copper might be

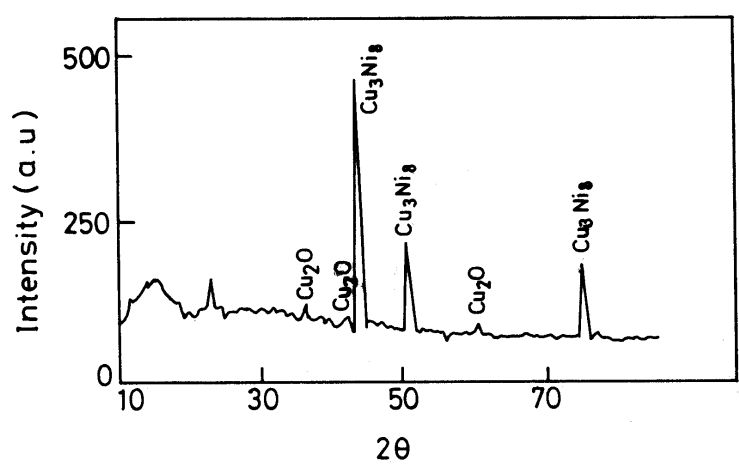

Figure 6. XRD pattern of alloy $\mathrm{C}$ kept at $+200 \mathrm{mV}$. 


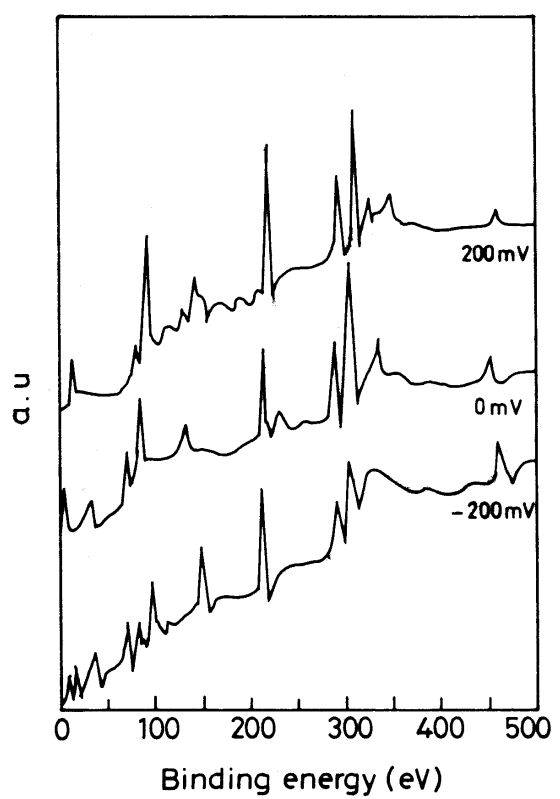

Figure 7. ESCA survey spectra $(0-500 \mathrm{eV})$ of alloy $\mathrm{C}$ kept at various anodic potentials.

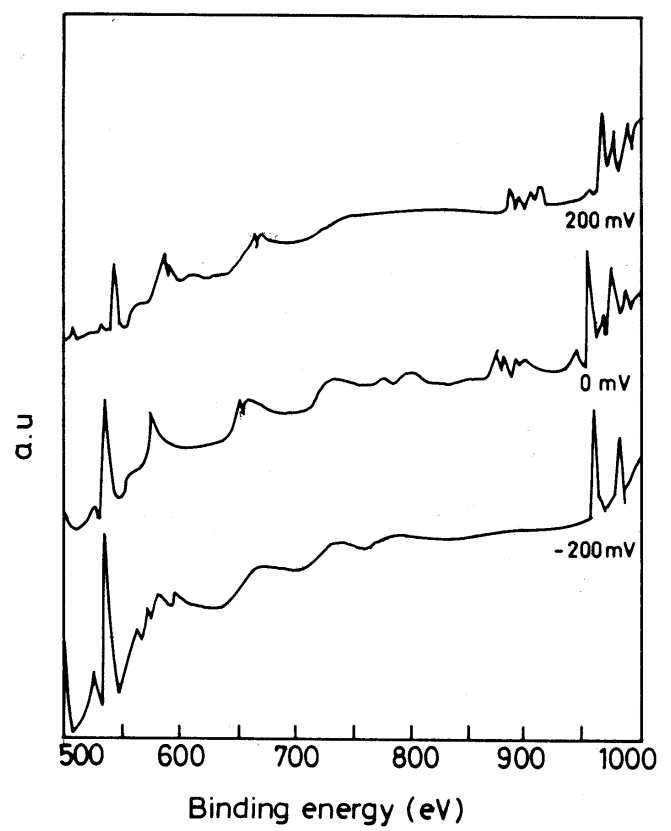

Figure 8. ESCA survey spectra $(500-1000 \mathrm{eV})$ of alloy C kept at various anodic potentials. 
present in the cuprous form. The $\mathrm{O}_{1 s}$ peak was asymmetric at all potentials with a maximum of $537 \mathrm{eV}$ with a higher binding energy shoulder at $533 \mathrm{eV}$. The relative shift in the $1 s$ peak and the appearance of the shoulder clearly indicated the presence of oxygen in the oxide-metal (O-M peak) binding state. The electrode kept at $200 \mathrm{mV}$ exhibited the presence of satellite structure in addition to the $2 P 3 / 2$ peak, corresponding to the divalent copper in addition to the monovalent copper. The relative shift between the $2 P 3 / 2$ and $2 P 1 / 2$ was found to be $20 \mathrm{eV}$ instead of $19.8 \mathrm{eV}$ (for pure copper) confirming the presence of $\mathrm{CuO}$ in the surface film. The spectra of copper compound established that the shake-up satellite structure was closely related to the oxidation state of copper. The $2 p$ spectra of the cupric compounds showed satellite peaks arising from multi-electron excitation accompanying X-ray induced photo ionization.

\section{Discussion}

In the case of alloy dissolution ${ }^{14}$ one would expect (a) both copper and nickel to leave the metal lattice, and/or (b) copper to dissolve and enter the solution.

In all chloride solutions studied, anodic and cathodic peak potentials varied with chloride ion concentration. At concentrations $>0.05 \mathrm{M}$, alloys $\mathrm{A}$ and $\mathrm{B}$ showed two distinct anodic peaks $A_{1}$ and $A_{2}$ in the forward scan. The appearance of peak $A_{1}$ is due to the formation of $\mathrm{Cu}_{2} \mathrm{O}$ via $\mathrm{CuCl}_{2}^{-}$which is an intermediate ${ }^{15,16}$,

$$
\begin{aligned}
& \mathrm{Cu}+2 \mathrm{Cl}^{-} \rightarrow \mathrm{CuCl}_{2}^{-}+e, \\
& 2 \mathrm{CuCl}_{2}^{-}+\mathrm{H}_{2} \mathrm{O} \rightarrow \mathrm{Cu}_{2} \mathrm{O}+4 \mathrm{Cl}^{-}+2 \mathrm{H}^{+} .
\end{aligned}
$$

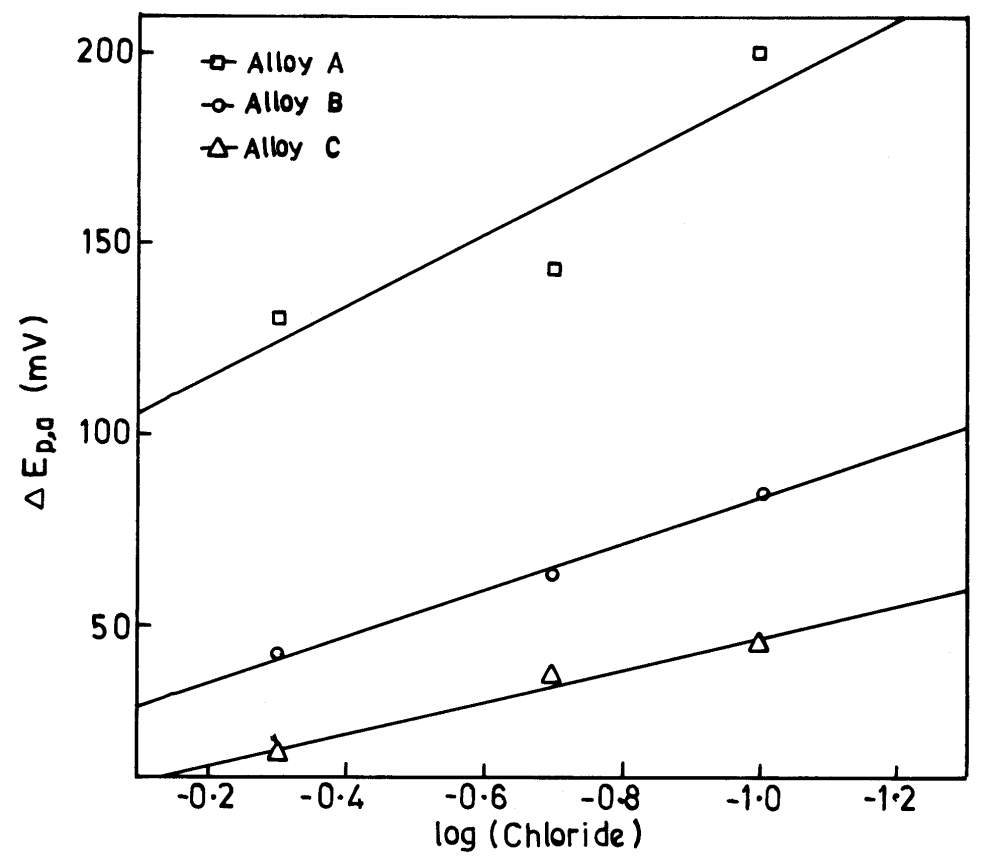

Figure 9. Peak potential separation $\left(\Delta E_{p}\right)$ vs log chloride concentration for various cupronickel alloys. 
At extreme anodic potentials the appearance of peak $\mathrm{A}_{2}$ suggests that $\mathrm{Cu}_{2} \mathrm{O}$ would be oxidised to $\mathrm{CuO} / \mathrm{Cu}(\mathrm{OH})_{2}$.

$$
\begin{aligned}
& \mathrm{Cu}_{2} \mathrm{O}+\mathrm{H}_{2} \mathrm{O} \rightarrow 2 \mathrm{CuO}+2 \mathrm{H}^{+}, \\
& \mathrm{Cu}_{2} \mathrm{O}+3 \mathrm{H}_{2} \mathrm{O} \rightarrow 2 \mathrm{Cu}(\mathrm{OH})_{2}+2 \mathrm{H}^{+} .
\end{aligned}
$$

The Nernst equation for (1) is,

$$
\begin{aligned}
E_{\mathrm{e}}= & E_{\mathrm{e}}{ }^{\circ}+2 \cdot 303 R T / F \log \left[\mathrm{CuCl}_{2}^{-}\right] /[\mathrm{Cu}]\left[\mathrm{Cl}^{-}\right]^{2}, \\
\Delta E_{\mathrm{p}} & =E_{p, a}-E_{p, c}=\text { peak potential separation } \\
& =\left(E_{p, c}-E_{e}\right)-\left(E_{p, a}-E_{e}\right) \\
& =2 \cdot 303 R T / F \log \left[\mathrm{CuCl}_{2}^{-}\right] /[\mathrm{Cu}]\left[\mathrm{Cl}^{-}\right]^{2}
\end{aligned}
$$

The $\mathrm{CuCl}_{2}^{-}$undergoes chemical reaction to form $\mathrm{Cu}_{2} \mathrm{O}$. This suggests chloride ion participation in film formation. Figure 9 presents the peak potential separation $\left(\Delta E_{p}\right)$ with $\log$ chloride ion concentration which confirms this. Scanning electron microscope picture (figure 10a) obtained on alloy $\mathrm{C}$, when viewed at 1000 magnification, suggests the coverage of the surface by massive, voluminous, interconnecting crystals; on further magnification (figure 10b), rhombic and cubic crystals were seen. The surface of the base alloy was also seen. The base alloy substrate was covered completely after prolonged anodic polarisation.

An increase of chloride ion concentration in solution and copper content in the alloy caused the appearance of inverted anodic peaks, a net flow of anodic current. These suggest a predominant dissolution of the less noble component in the alloy through the pores of the passive film formed on the surface of the alloy (figure 10c).

The model for passivation was proposed by Muller ${ }^{17,18}$, and describes the growth of the film only at certain points on the alloy and extends over the surface as a layer of uniform thickness $(\delta)$. This film formation is controlled by Ohmic resistance. If the total area of the electrode is $A_{\mathrm{o}}$ and $\theta p$ is the degree of coverage of the electrode, the resistance of the solution in the pores threading the layer is,

$$
R_{p}=\delta / K A_{\mathrm{o}}\left(1-\theta_{p}\right)
$$

where $\delta$ is the thickness of the film and $K$ is the specific conductivity of the solution inside the pores. The expressions for peak current and peak potential are

$$
\begin{aligned}
& i_{p, a}=\left((n F \rho K)^{1 / 2} / M^{1 / 2}\right) A_{o}\left(1-\theta_{p}\right) v^{1 / 2}, \\
& E_{p, a}=E_{o}+\left((n F \rho K)^{1 / 2} / M^{1 / 2}\right)\left\{(\delta / K)+R_{o} A\left(1-\theta_{p}\right)\right\} v^{1 / 2},
\end{aligned}
$$

where $n=$ number of electrons involved in the electrochemical reaction, $\rho=$ film density; and $R_{o}$ is the resistance of the solution external to the film. As suggested by the above equations the anodic peak current reaches zero as the sweep rate tends to zero. Anodic peak $\left(A_{1}\right)$ potentials were extrapolated to zero sweep rates (figure 11). The intersection 
potential $E_{a}^{o}$ is the minimum potential needed for current flow, i.e. film formation potential. The decrease in copper content in the alloy shifts the $E_{a}^{o}$ to nobler values suggesting an hindrance to the film formation. Chloride ion concentration favours the film formation as indicated by the shift of $E_{a}{ }^{o}$ to less noble values (table 2).

Monovalent copper film formation occurs at peak potential $A_{1}$. The surface coverage $\theta_{p}$ after the peak $A_{1}$ was calculated assuming the $\rho$ of $\mathrm{Cu}_{2} \mathrm{O}$ as $6.0 \mathrm{~g} / \mathrm{cc} ; M=$ molecular weight of $\mathrm{Cu}_{2} \mathrm{O}=143.09 \mathrm{~g} / \mathrm{mol} ; K=10^{-2} \mathrm{ohm}^{-1} \mathrm{~cm}^{-1}$ in the preceding equations.
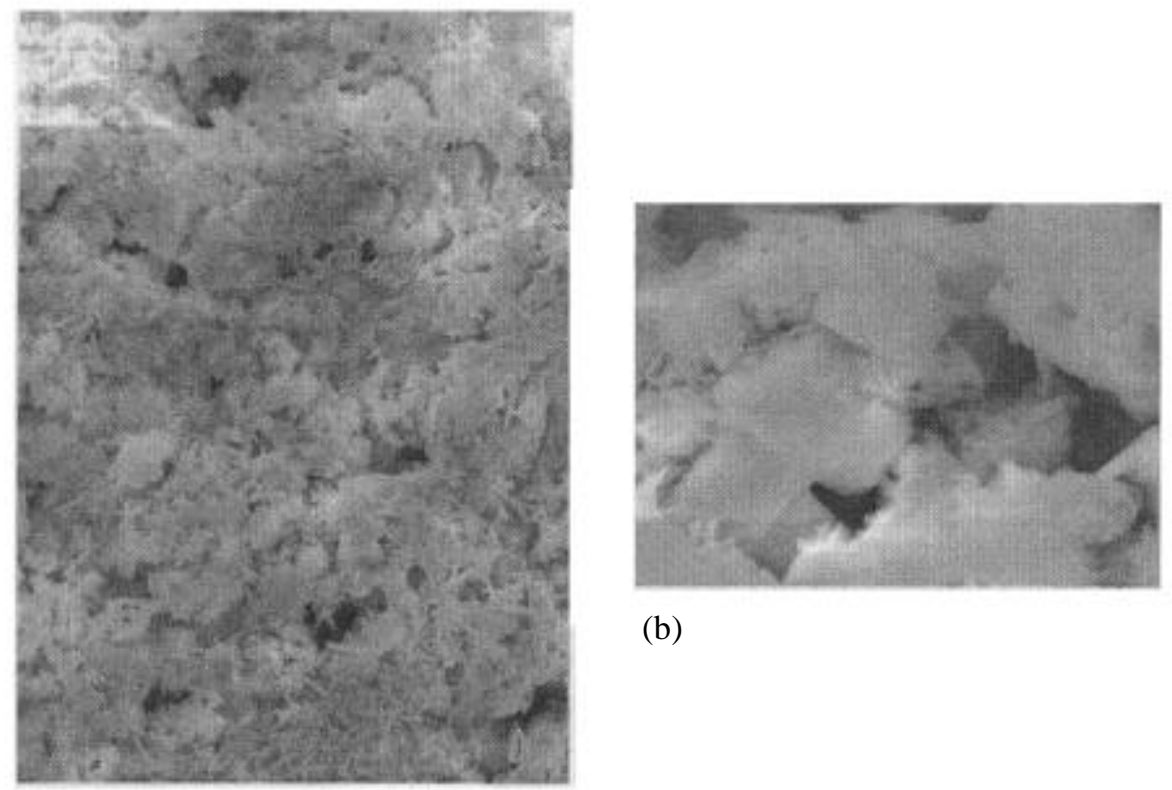

(b)

(a)

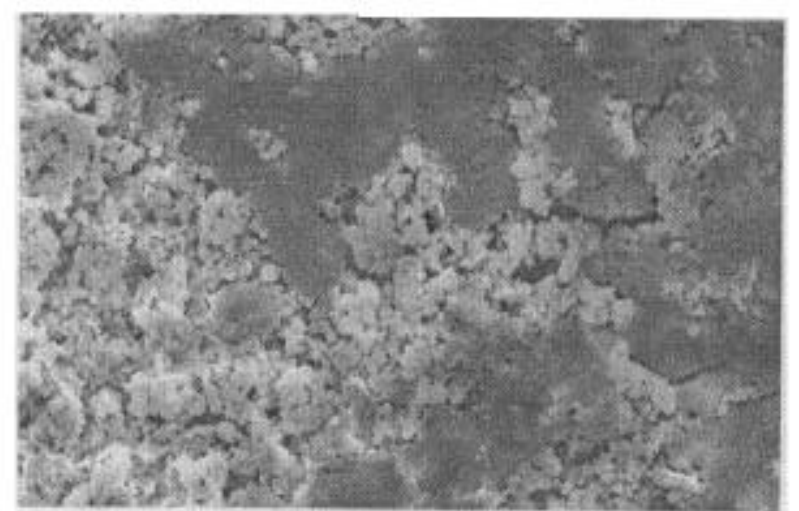

(c)

Figure 10. Scanning electron micrograph of alloy $\mathrm{C}$, obtained by scanning the electrode potential from -200 to $600 \mathrm{mV}$ vs $\mathrm{SCE}$ at $10 \mathrm{mV} / \mathrm{s}$ in $0.5 \mathrm{M} \mathrm{NaCl}$ (a) $\times 1000 ;($ b $) \times 7000 ;(\mathbf{c}) \times 350$. 
Table 2. Variation of $E_{a}^{o}(\mathrm{mV}$ vs SCE) with chloride ion concentration for different cupronickel alloys.

\begin{tabular}{lrrr}
\hline Concentration of chloride (M) & Alloy A & Alloy B & Alloy C \\
\hline $0 \cdot 1$ & 220 & 270 & 290 \\
$0 \cdot 2$ & 130 & 150 & 200 \\
$0 \cdot 5$ & -10 & 5 & 25 \\
\hline
\end{tabular}

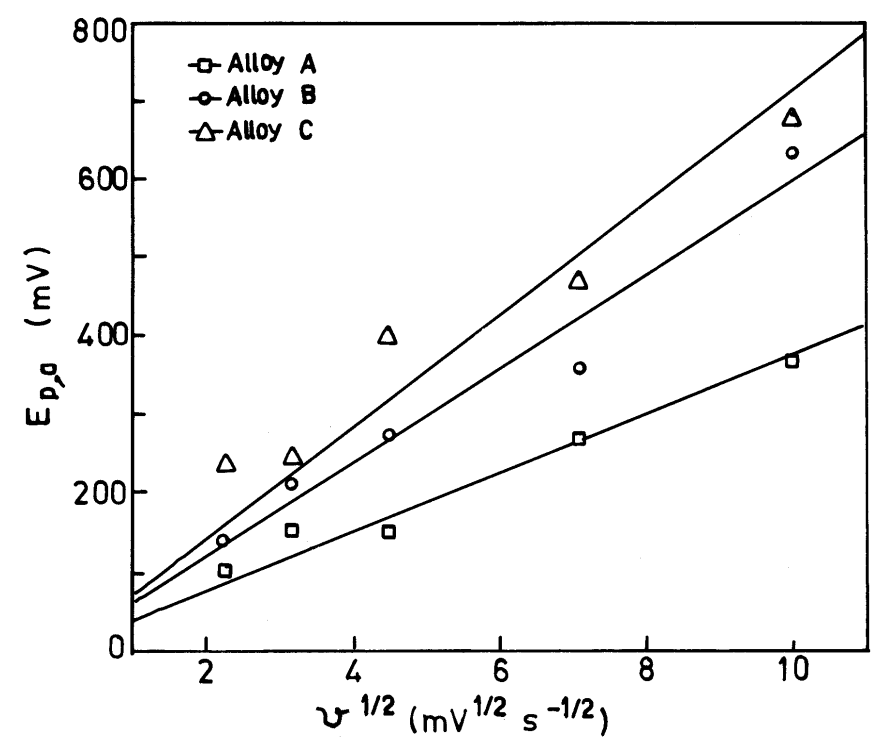

Figure 11. Anodic peak potential vs square root of sweep rates for various cupronickel alloys in $0.5 \mathrm{M}$ chloride solutions.

The thickness of the film $\delta$, and the ohmic resistance $R$ of the film were calculated.

The rise in chloride ion concentration did not affect markedly the film thickness (figure 12) while the film resistance decreased for all the alloys (figure 13). $\mathrm{Cu}_{2} \mathrm{O}$ film growth was invariant with chloride ions while its conductance was affected by them.

\section{Solid-state passivation model}

When cupronickel is subjected to prolonged anodic polarisation the dissolution of copper may give rise to $\mathrm{CuCl}_{2}^{-}$which in turn becomes $\mathrm{Cu}_{2} \mathrm{O}$. The alloy surface is covered by the film. The copper ion concentration within the film thickness decreases gradually. The migration of monovalent copper ions away from the alloy surface generates cation vacancies ${ }^{19}$ as

$$
\mathrm{Cu}_{\mathrm{Cu}}(\mathrm{ox}) \rightarrow \mathrm{Cu}^{+} \text {(aq.) }+\mathrm{V}_{\mathrm{Cu}}^{\prime}(\mathrm{ox})
$$

where $\mathrm{Cu}_{\mathrm{Cu}}$ (ox) is a monovalent copper ion site inside the film; $\mathrm{V}_{\mathrm{Cu}}^{\prime}$ (ox) is vacancy of copper ions. 


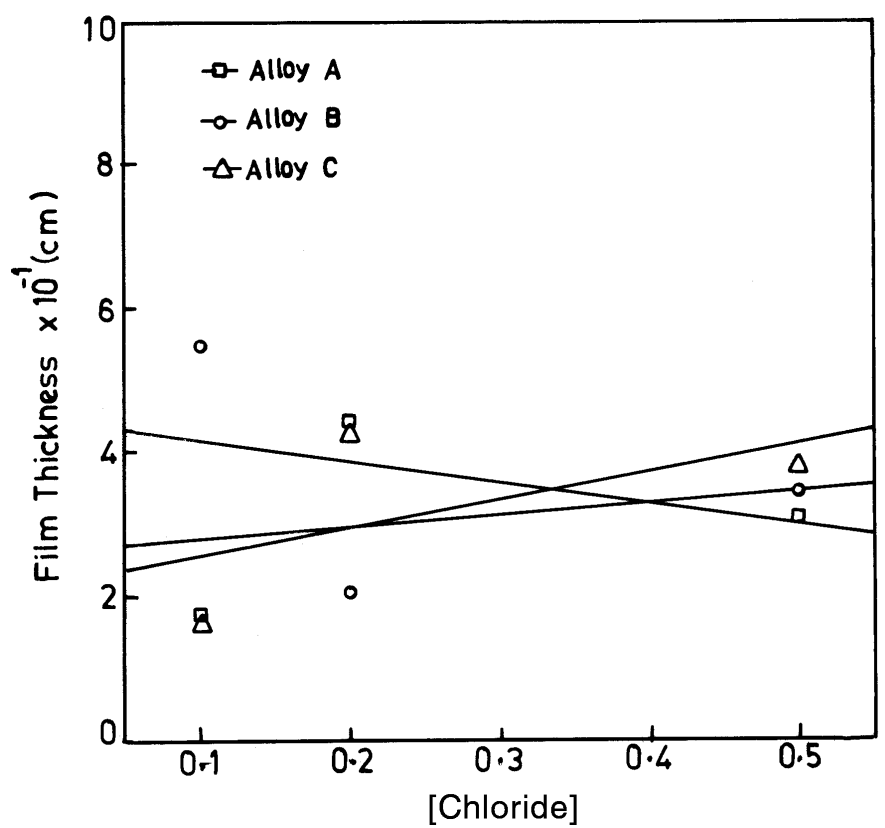

Figure 12. Film thickness $(\delta)$ vs chloride concentration for various cupronickel alloys.

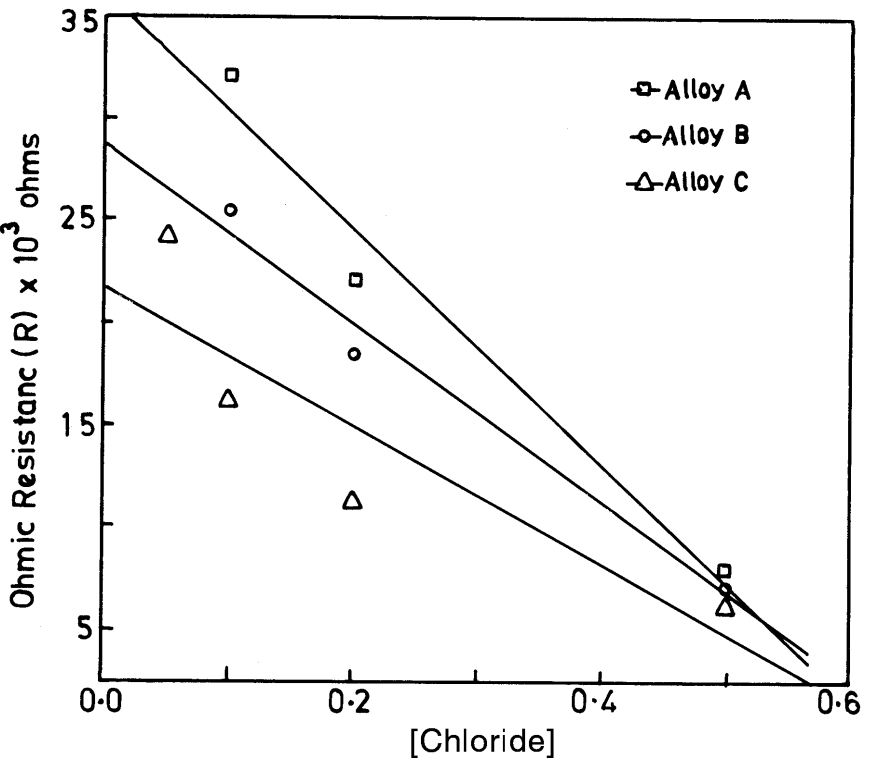

Figure 13. Ohmic resistance $(R)$ vs chloride concentration for various cupronickel alloys.

When the electrode is made anodic, the cations move away from the electrode while cation vacancies travel towards it, 


$$
\mathrm{Cu}_{\mathrm{Cu}}(\mathrm{M})+\mathrm{V}_{\mathrm{Cu}}^{\prime}(\mathrm{ox}) \rightarrow \mathrm{Cu}_{\mathrm{Cu}}(\mathrm{ox})+\mathrm{V}_{\mathrm{cu}}(\mathrm{M})+e,
$$

where $\mathrm{Cu}_{\mathrm{Cu}}(\mathrm{M})$ is the cationic site in the alloy, $\mathrm{V}_{\mathrm{cu}}(\mathrm{M})$ is the vacancy created by the copper cation in the alloy.

When nickel dissolution potential is reached, $\mathrm{Ni}^{2+}$ ions try to occupy the cation vacancies,

$$
\mathrm{Ni}_{\mathrm{Ni}}(\mathrm{M})+\mathrm{V}_{\mathrm{Cu}}^{\prime}(\mathrm{ox}) \rightarrow \mathrm{Ni}_{\mathrm{Cu}}(\mathrm{ox})+2 e,
$$

where $\mathrm{Ni}_{\mathrm{Cu}}$ (ox) is the site where nickel divalent cation occupies the vacancy created by copper in the oxide. With the passage of time, outward diffusion of nickel ions occurs from the alloy/film interface to the inside of the film. This generates additional cation vacancies in the alloy. As the formation of soluble $\mathrm{NiCl}_{2}$ is more favourable than that of $\mathrm{CuCl}_{2}$, nickel ions leave faster from the oxide layer, which in turn generates further vacancies in the film,

$$
\mathrm{Ni}_{\mathrm{Cu}} \mathrm{V}_{\mathrm{Cu}} \rightarrow \mathrm{Ni}^{2+} \text { (aq.) }+2 \mathrm{~V}_{\mathrm{Cu}}^{\prime} \text { (ox) }
$$

Chloride ions adsorb on the surface of the film and try to occupy the vacancies created by the oxygen ions of $\mathrm{Cu}_{2} \mathrm{O}^{20-23}$. The inward diffusion from the solution/film interface inside the film is facilitated by anodic polarization,

$$
\mathrm{V}_{\mathrm{O}}(\mathrm{ox})+\mathrm{Cl}^{-} \rightarrow \mathrm{Cl}_{\mathrm{O}}(\mathrm{ox})
$$

As the chloride ion incorporation in the film increases, the number of oxygen vacancies occupied by chloride ions also increases. Chemical stability is decided by the copper and chloride ions ratio in this film. When the atomic ratio of $\mathrm{Cu}^{+}: \mathrm{Cl}^{-}$exceeds 1 , the film becomes unstable and dissolution occurs from the areas where the chloride ion concentration is greater (see figure 10c).

\section{Conclusions}

In chloride solutions cupronickels form $\mathrm{Cu}_{2} \mathrm{O}$ films on anodic polarisation. Chloride ions adsorb on the surface and occupy the oxygen vacancies in the film. Nickel content in the alloy and chloride ion concentration in solution decrease the resistance of $\mathrm{Cu}_{2} \mathrm{O}$ films. Nickel ions generate cation vacancies in the film when the conditions of $\mathrm{NiCl}_{2}$ formation are favoured. The $\mathrm{Cu}: \mathrm{Cl}^{-}$ion ratio in the film of $\mathrm{Cu}_{2} \mathrm{O}$ decides the chemical stability of $\mathrm{Cu}_{2} \mathrm{O}$ and if the ratio exceeds one, dissolution of oxide occurs.

\section{Acknowledgement}

One of the authors (JM) expresses his sincere thanks to the Council of Scientific \& Industrial Research, New Delhi for a fellowship.

\section{References}

1. Uhlig H H 1944 Trans. Electrochem. Soc. 85307

2. Uhlig H H 1958 Z. Electrochem. 62700 
3. Dhar H P, White R E, Darby R, Cornwell L R, Griffin R B and Burnwell G 1985 Corrosion 41 193

4. Beccaria A M and Crousier J 1989 Br. Corros. J. 2449

5. Popplewell J M, Hart R J and Forrd J A 1973 Corros. Sci. 13295

6. North R F and Pryor M J 1968 Corros. Sci. 8149

7. Shih H and Pickering H W 1987 J. Electrochem. Soc. 1341949

8. Chauhan P K and Gadiyar H S 1985 Corros. Sci. 2555

9. Eiseltein L E, Syrett B C, Wing S S and Caligiuri R D 1983 Corros. Sci. 23223

10. Mathiyarasu J, Palaniswamy N and Muralidharan V S 1999 Port. Electrochim. Acta 1745

11. LaQue F L 1941 J. Am. Nav. Eng. 539

12. Mansfeld F and Uhlig H H 1969 Corros. Sci. 9377

13. Milosev I and Metikos-Hukovic M 1997 Electrochim. Acta 421537

14. Lee H P and Nobe K 1985 J. Electrochem. Soc. 1321031

15. Milosev I and Metikos-Hukovic M 1991 J. Electrochem. Soc. 13861

16. Pickering H W and Wagner C 1967 J. Electrochem. Soc. 114698

17. Muller W J 1931 Trans. Faraday Soc. 27737

18. Muralidharan V S, Thangavel K and Rajagopalan K S 1983 Electrochim. Acta 231611

19. Urquidi M and Macdonald D D 1985 J. Electrochem. Soc. 132555

20. Urquidi-Macdonald M and Macdonald D D 1989 J. Electrochem. Soc. 136961

21. Chao C Y, Lin L F and Macdonald D D 1981 J. Electrochem. Soc. 1281187

22. Lin L F, Chao C Y and Macdonald D D 1981 J. Electrochem. Soc. 1281194

23. Macdonald D D, Ben-Haim D D and Pallix J 1989 J. Electrochem. Soc. 1363269 